\title{
Yield and phosphorus efficiency of some lowland rice varieties at different levels of soil- available phosphorus
}

\begin{abstract}
A field experiment was conducted on an Aeric Haplaquept soil to study the effect of phosphorus $(\mathrm{P})$ deficiency in soil on the $\mathrm{P}$ nutrition and yield of five modern varieties of rice, viz., Purbachi, BR1, BR3, BR14, and BR29, popular with the rice farmers of Bangladesh. Soil-available $\mathrm{P}$ in the different plots of the experimental field varied widely, from 2.8 to 16.4 $\mathrm{ppm}$. This plot to plot variation in soil-available $\mathrm{P}$ content resulted from differences in the total amounts ( 0 to $480 \mathrm{~kg}$ ha -1 ) of $\mathrm{P}$ the plots had received over a period of 8 years in a long-term $\mathrm{P}$ fertilizer trial conducted previously in the same field. Phosphorus deficiency in soil drastically reduced the grain yield of all the rice varieties. In severely $\mathrm{P}$ deficient plots, where soil-available $\mathrm{P}$ was around $3 \mathrm{ppm}$, the yield was less than 1 ton ha -1 while in plots containing an adequate $\mathrm{P}$ level, i.e., $>6 \mathrm{ppm}$, the yield was more than $4 \mathrm{t}$ ha -1 . Rice yield increased linearly with an increase in soil P content up to $6 \mathrm{ppm}$, and the highest grain yield for any variety, obtained at 6-7 ppm of soil-available P leveled off at this point. Soil P deficiency not only decreased rice yield severely but also decreased $\mathrm{P}$ content in straw and grain drastically. However, differences among rice varieties were noted in $\mathrm{P}$ nutrition, particularly at low soil $\mathrm{P}$ levels. The rice varieties differed markedly also in respect of internal P efficiency. The BR29 showed the highest internal P efficiency both at low and high soil $\mathrm{P}$ levels. In all the rice varieties, internal $\mathrm{P}$ efficiency decreased with an increase in soil $\mathrm{P}$ levels.
\end{abstract}

Keyword: Phosphorus; Rice; Soil fertility; Yield response 